\author{
Schmidt M., Pearson O. (2016): Pastoral livelihoods under pressure: Ecological, \\ political and socioeconomic transitions in Afar (Ethiopia). In: Journal of Arid
}

Environments 124, 22-30. DOI: http://dx.doi.org/10.1016/j.jaridenv.2015.07.003.

\title{
Pastoral livelihoods under pressure: Ecological, political and socioeconomic transitions in Afar (Ethiopia) \\ Matthias Schmidt and Olivia Pearson
}

\begin{abstract}
The Afar pastoralists that reside in arid and semi-arid regions of Ethiopia have fallen under increasing pressure as rangelands and natural resources are affected by recurrent droughts, overgrazing, erosion processes, alien plant invasion and governmental land policies. This paper investigates the impact of these environmental, institutional and cultural changes on natural resource management strategies, using empirical research undertaken in four villages of western Afar (Ethiopia) to assess the related challenges to local livelihoods. Qualitative interviews with various stakeholders reveal that the authority and use of traditional common property regimes have been considerably diminished and traditional livelihood practices threatened. Many pastoralists have adopted agriculture in a move away from pure pastoralism to agro-pastoralism, a transition exaggerated by changing property rights and the Federal Government's sedentarisation program, which is presented as a means of reducing poverty. On-going land privatisation and an increased government presence in the region weaken indigenous institutions and cultural practices, with no clear local understanding of the impact on future generations and Afar identity.
\end{abstract}

Keywords: Pastoralism Indigenous knowledge Natural resource management Property rights

\section{Introduction}

The arid and semi-arid regions that cover close to one third of land worldwide are challenging living spaces that offer limited resources and require elaborate adaptation measures. Over centuries people residing within such harsh environments have developed appropriate livelihood management strategies (Berhanu et al., 2007; Mwangi and Dohrn, 2008; Nassef et al., 2009; Tsegaye et al., 2013). However, as a consequence of recent processes such as climate change, population growth, environmental deterioration, modernisation efforts, and growing state influence, these livelihoods have fallen increasingly under pressure (Meier et al., 2007; Kassahun et al., 2008; Okello et al., 2009; Sulieman and Elagib, 2012).

Worldwide, sparsely populated semi-arid regions are gaining more attention than in the past, when state policies were often characterised by ignorance towards such peripheries (Nassef et al., 2009; Whitfield and Reed, 2012). This increased awareness is connected to an enhanced ability of governments to implement widespread changes in infrastructure, education, and political control, as well as growing interest in the emerging risks and potentials of these environments.

The effects of climate change processes such as rising maximum temperatures and increasingly irregular rainfall are particularly pronounced in semi-arid areas (Ayantundea et al., 2011; Sietz et al., 2011). Exacerbated by population growth and environmental degradation, natural resources essential for rural livelihoods have become scarcer, resulting in a deterioration in living conditions (Sietz et al., 2011; Headey et al., 2014) and a potential increase in conflict (Raleigh and Kniveton, 2012). Areas seen as unused or only marginally utilised e at least in the eyes of external actors such as national governments e have become attractive for politicians and investors, leading to large-scale investments and restructuring projects that combine physical measures on the ground with political and institutional changes (MFEDEPPD, 2003; Galaty, 2013; Easdale and Domptail, 2014).

In recent years, the formalisation of property rights has allowed for large-scale land acquisitions e often termed as land grabbing e in sub-Saharan Africa (Borras et al., 2011; Cotula, 2012; Lavers, 2012a; Smalley and Corbera, 
2012; Woodhouse, 2012; Peters, 2013). Investment in land, promising new infrastructure and employment, is attractive for governments of financially poor, but land-rich countries (ANRS, 2008; Alden Wily, 2011; Galaty, 2013). Land privatisation, i.e. transferring ownership rights, encourages interest in agriculture by stimulating a move from semi-nomadic pure pastoralist livelihoods to agro-pastoralism, a combination of arable farming and animal husbandry (Sonneveld et al., 2010). Land privatisation is also justified as a means of enhancing agricultural productivity "based on the assumption that land titling will lead farmers and herders to make greater investments in their production systems" (Bassett, 2009, 756).

The trend towards formalisation of property rights poses serious, sometimes existential, threats to local inhabitants. As traditional land use is usually based on customary law without formally secured property rights, indigenous land titles are often viewed as tenuous and local utilisation practices ignored (Alden Wily, 2011, 2012). Governmental influence through the establishment of infrastructures, irrigation schemes or reserve zones means a de jure change in property rights and a de facto expropriation from the people who formerly used these lands. However, while there are undoubtedly vast areas in sub-Saharan Africa that seem only marginally used and where productivities could be enhanced, they are almost never completely idle and remain significant for local livelihoods (Bassett, 2009; Odote, 2013). In particular, pastoralists in (semi)-arid regions with sparse vegetation cover require large ranges for animal husbandry (Onono et al., 2013).

Natural resources such as rangelands are often classified as common pool resources and are used and managed by local communities through common property regimes. Management and utilisation of these relatively lowproductivity resources normally necessitates extra labour input, joint efforts, and regulations. Other attributes of common property regimes include the costly exclusion or problematic control of user access and subtractability, by which each user is capable of subtracting from the welfare of other users (Berkes, 1989; Ostrom et al., 2002). However, in contrast to Garrett Hardin's famous Tragedy of the Commons (Hardin, 1968), which states that utilisation of natural resources by groups inevitably leads to overuse and degradation, Elinor Ostrom (1990, 2009; Ostrom et al., 2002) and many other scholars (Berkes, 1989; Hanna et al., 1996; Agrawal, 2001, 2014; Araral, 2014) show that in certain circumstances management of natural resources by groups or communities is superior to both individual ownership and state ownership. Worldwide, numerous local institutions use common property regimes to successfully and sustainably regulate land and natural resources, regimes essential to the livelihoods of millions of people.

In semi-arid areas of Africa, pasture is traditionally managed through common property regimes that are highly adapted to difficult environmental conditions. The mobility of pastoralists and their herds as well as the flexibility of their common property regimes are rational strategies to withstand droughts, in spite of the variable nature of semi-arid rangelands (Behnke et al., 1993). Institutions regulating access and utilisation of grazing lands are usually flexible and retained through complex social networks and negotiations (Cousins, 2007).

Ostrom (1990) emphasised that trust, reciprocity, and communication are required for successful common property regimes and identified eight design principles for successful common property regimes: clear boundaries, congruent rules, collective choice arrangement, monitoring, graduated sanctions, conflict resolution, organisation rights, and nested units. Without going deeper into the discussion and critiques of the design principles (Agrawal, 2001; Quinn et al., 2007; Cox et al., 2010) Ostrom's principles not only help to identify threats to existing common property regimes undergoing current transformation processes but they may also be used to address problems associated with designing fair and sustainable resource management institutions. On the basis of investigations in Tanzania, Quinn et al. (2007) stress the importance and need for flexibility in areas characterised by ecological uncertainty and state the usefulness of the design principles as a framework but warn against using them as a blueprint.

Despite being flexible, pastoral commons, described by Agrawal (2014) as "coupled natural and human systems", and their property regimes have fallen increasingly under pressure due to the aforementioned convergence of external influences (e.g., climate change, state interventions, profit-oriented measures by private actors) and internal developments (e.g., population growth, environmental degradation, conflicts). Bennett el al. (2010) see the inability to define and enforce user rights, inadequate local institutions, diffuse user groups, and ethnic and political divisions as barriers to common rangeland management in South Africa, where the transformation from traditional to new management practices has led to greater economic disparities (Lebert and Rohde, 2007). Mwangi (2007) uses the example of the Maasai in Kenya to show how land privatisation can destabilise land 
holdings and promote inequality, while Bassett (2009) outlines how new land law leading to modified access and control of lands for pastoralists threatens livestock raising systems in Côte d'Ivoire.

The lowlands of eastern Ethiopia epitomise these transitions as environmental changes and government modernisation efforts challenge pastoralists' traditional livelihood practices (Abule et al., 2005; Davies and Bennett, 2007; Rich_e et al., 2009; Tsegaye et al., 2010a, b; 2013). Using the example of the Afar ${ }^{1}$ people from one of Ethiopia's four pastoral regions, this paper assesses current transitional processes in (1) Natural Resource Management, (2) Property Rights, and (3) Livelihoods by asking the following questions: What are the current transitions of natural resource management in Afar, both as adaptation strategies to environmental and socioeconomic changes and as consequences of political initiatives? How do institutional changes like transforming property rights and the government sedentarisation scheme alter traditional authorities, autochthonous common property regimes, and local communities? The results show how challenges to and the impact of current socio-economic conditions are perceived by the Afar, and how they are managed by the various institutions. The discussion outlines the connotations of pastoralist and agro-pastoralist livelihood types and their effect on Afar culture. The conclusions describe the steps that should be considered when redesigning natural resource management systems in Afar.

\section{Research methodology}

This study refers to the Afar National Regional State $(96,707 \mathrm{~km} 2)$ of the Federal Democratic Republic of Ethiopia. Research was conducted in four kebeles (villages) of Ewa and Awra Woreda (district) within Zone Four (Fig. 1). According to the latest official numbers (ANRS, 2011a, b), around 47,000 inhabitants live in Ewa (127,700 ha) with a population density of 37 persons per square kilometre, while Awra (309,600 ha) is less populated with around 36,000 inhabitants or 12 persons per square kilometre. Kebeles were selected with the cooperation of government and NGO officials working in the region to ensure that those with different subsistence bases were studied, i.e. they had been classified by the government as either "agro-pastoralist" or "pastoralist". For each kebele we documented the availability of natural resources, the presence of indigenous knowledge and local institutions, access to governmental and humanitarian aid, and the perceived economic standing of the community. Through this process, we sought insight into the complex convergence of factors affecting local life. Four kebeles were chosen: Hida (agro-pastoralist) and Hiddalu (pure pastoralist) in Awra, and 1st Batoli (agropastoralist) and Buti (pure pastoralist) in Ewa.

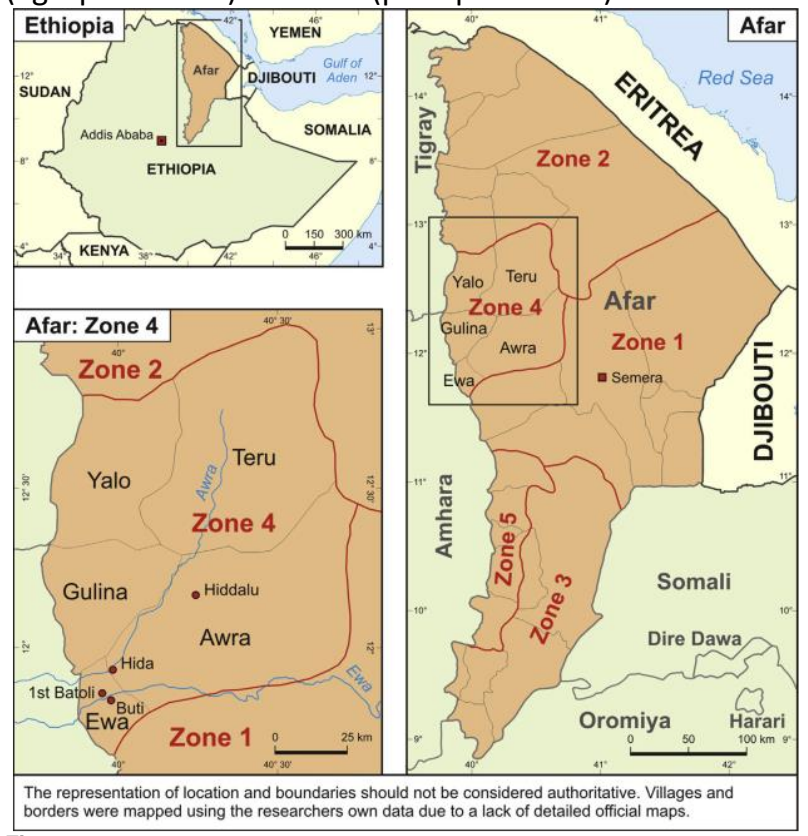

Fig. 1. Location of the study area in Afar, Ethiopia.

\footnotetext{
11 Afar stands for the region that extends into Eritrea and Djibouti, an ethnicgroup, and a language that belongs to the Cushitic branch of the Hamito-Semitic language family.
} 
Primary qualitative data were generated from fieldwork conducted during October and November 2013 and March 2014. Ethnographic rural fieldwork included 20 semi-structured qualitative group interviews (12 male, four female, and four male and female) and 27 in-depth, semi-structured qualitative interviews with key informants (22 male, five female). Rural key informants include local stakeholders, village elders and clan leaders, with informal interviews and conversations also carried out at social gatherings, during meals, and at watering points to obtain the female perspective. The formal institutional perspective comes from 15 in-depth interviews (14 male, one female) and one focus group (male) held in both the field and the cities of Semara, Logia, and Addis Ababa with representatives from the Bureau of Pastoral and Agricultural Development (BoPAD), the Water Department and NGOs. Table 1 provides a list of the gender, age and occupation of those who participated in formal interviews and focus groups. Researchers also reviewed previous studies, relevant policies, legislation and reports pertaining to natural resource management and property rights in Afar.

To analyse present threats to and influences on the Afar pastoral commons as well as the transition of pastoral livelihoods, we used three significant interacting indicators: environmental, institutional, and cultural change. These indicators were used to identify the differences between the past and present states of our research foci. Pastoralist livelihoods are intrinsically connected to and heavily dependent on the availability of and access to natural resources. Recognised environmental changes in the Afar region include recurring droughts, degradation of rangelands, soil erosion, and flash flooding, changes aggravated by deforestation and overgrazing (Tsegaye et al., 2010a; Aynekulu et al., 2012). Each informant was questioned about the past and present state of natural resources and was asked to describe the landscape of their youth compared with today. Native and alien plants were listed, with information sought on their previous and current prevalence, their uses, and the impact of their loss or introduction on the land and people. Participants provided their understanding of why availability and quality of natural resources have changed, the catalysts for these changes, and their ramifications. Each participant was asked to describe what natural resource management techniques are used in the region, the processes that lead to a change in preferred techniques, and their outcomes.

Table 1

Demographics of formal interview participants.

\begin{tabular}{|c|c|c|c|c|c|c|c|}
\hline & Hida & Hiddalu & 1st Badoli & Buti & $\begin{array}{l}\text { Other rural } \\
\text { areas }\end{array}$ & $\begin{array}{l}\text { Non- } \\
\text { rural }\end{array}$ & Total \\
\hline Total interviewed & 35 & 19 & 27 & 23 & 27 & 8 & 139 \\
\hline $\begin{array}{l}\text { Individual } \\
\text { Interviewee }\end{array}$ & 8 & 7 & 4 & 6 & 7 & 5 & 37 \\
\hline $\begin{array}{l}\text { Group Interviewee } \\
\text { Gender }\end{array}$ & 27 & 12 & 23 & 17 & 20 & 3 & 102 \\
\hline Male & 35 & 9 & 16 & 14 & 23 & 7 & 104 \\
\hline $\begin{array}{l}\text { Female } \\
\text { Age }\end{array}$ & & 10 & 11 & 9 & 4 & 1 & 35 \\
\hline $30<$ & 6 & 2 & 4 & 4 & 2 & 2 & 20 \\
\hline 31 to 45 & 16 & 8 & 10 & 9 & 15 & 4 & 62 \\
\hline 46 to 60 & 8 & 6 & 10 & 10 & 9 & & 43 \\
\hline $\begin{array}{l}61> \\
\text { Occupation }\end{array}$ & 5 & 3 & 3 & & 1 & 2 & 14 \\
\hline Pastoralist & & 17 & 11 & 19 & 11 & & 58 \\
\hline Agro-pastoralist & 32 & & 15 & 1 & 11 & & 59 \\
\hline Other & 3 & 2 & 1 & 3 & 5 & 8 & 22 \\
\hline
\end{tabular}

Numerous formal and informal institutions influencenatural resource management in Afar through the creation and enforcement of guidelines and arrangements that define access, use, and ownership of natural resources (Mwangi and Dohrn, 2008). Formal institutions include government departments, NGOs, and foreign government agencies. Informal institutions include those functioning within clan structures, with significant actors being clan leaders, respected elders, and the members of various committees. Informants were asked to indicate the past and current relevance of these institutions and how they impact their lives and the area. Rural participants reflected on the validity and strength of formal and informal institutions, while institution employees detailed their job specific duties as well as their perception of their institution's role and impact. Cultural change is the third indicator. It is used in this paper to address the influence of complex transitions on Afar lives and livelihood practices to see how they make sense of and adapt to their changing surroundings. Cultural change highlights how clan life and traditions are not static but rather are in a constant state of transformation due to internal and external processes. Participants reflected on past and present cultural beliefs and practices, the 
significance of changes to these practices, how theses changes were brought about, and their future impact. The shift from communal to private land management and its related cultural repercussions were also addressed. This indicator facilitated an enhanced understanding of the pastoralist perspective, enabling greater insight into the actions of Afar pastoralists and their reactions to introduced policies and humanitarian aid.

Data obtained during fieldwork were recorded and analysed, a process combining observations with the results of formal and informal interviews and focus groups. Kebeles were assessed independently and then in relation to each other. Results compiled after initial fieldwork were discussed with (agro)-pastoralists from the focus kebeles then crosschecked through interviews held during the second fieldwork block with local leaders from six additional kebeles. A post-structural engagement, i.e. a discourse analytical view, was applied to document the pastoralists' perspective; this allows for a greater understanding when assessing the actions and reactions of Afar pastoralists to introduced policies and humanitarian work.

\section{Study area and traditional natural resource management}

The research site is located in Zone Four of the Afar National Regional State at the foot of the Ethiopian Highlands at altitudes between 800 and $1200 \mathrm{~m}$ and has a semi-arid climate (ANRS, 2011a, b). Two perennial rivers, Ewa and Awra, are found in the study area and are accompanied by several temporary water courses that appear after strong rainfalls. Flash floods originating in the highlands e previously a vital tool for rangeland regeneration e and various forms of erosion detrimentally affect pasturelands.

An understanding of traditional natural resource management is required in order to evaluate the impact of introduced management methods. The following section details traditional natural resource management practices with data primarily derived from interviews held with local leaders, elders and cultural experts. The nomadic Afar culture has created tools to sustain livelihoods based around mobility and resource access. The Afar migrate not only because of water and fodder scarcity, but also to allow rest periods for vegetation regeneration and to provide animals with a variety of fodder types. Iddo, the process of reconnaissance, is implemented prior to movement, with routes carefully plotted to maximise livestock and pastoralist security. "Afar don't look for one place, they go to four or five. They say this is the number one, two, three, four" (Cultural Expert, Logia, 7.11.2013). Potential stations (areas with water and/or fodder) are investigated then ranked against imperative criteria like the presence and level of resources and conflicts. Scouts use daagu (knowledge exchange) to communicate with each other, thereby accessing existing knowledge of rangeland conditions.

The Afar strategically mix their herds, which include camels, cattle, goats and sheep, to utilise various types of pasture and for security reasons; the loss of a specific group of livestock does not then automatically equate to the loss of a household's entire herd. Pastoralists use the condition of their livestock, their body shape, and milk quality to gauge pasture suitability and determine when movement should occur. They migrate with herds of varying size depending on the amount, strength and health of their livestock, e.g., whether they have just given birth and/or have young animals.

Afar customary law states that the wammo (primary residents) have preeminent usage rights of their ancestral domain, with proprietary rights that are communal and non-transferable (Hundie and Padmanbhan, 2008). Secondary access is granted to neighbouring pastoralists. Completely barring access to rangelands is forbidden, but restrictions can be applied. Desso (traditional rangeland management), for example, allows clans to regulate access to designated areas to prevent overgrazing. "Everyone has the right to protect his land for grazing, but desso can bring on fights with sticks, guns, knives. If someone gets hurt, the clan of the injured person will enact their revenge" (Female Elder, Hiddalu, 29.10.2013). It is a punishable offense to completely deny entry to rangelands; if access is restricted and animals die as a result, the deaths are attributed to those who imposed the restrictions. Traditional water utilisation and management is centred on access to perennial and seasonal rivers and the construction of water points. The most commonly constructed is the buyyi, a shallow temporary well dug along riverbanks. An ela, a well often deeper than ten meters, is a more permanent structure and less common. Boodas, uncovered wells in flooding plains, are created to catch water coming from the highlands. Coox dacayri, the protection of trees and rangelands, centres around a sound knowledge of the status of existing flora on rangelands within a clan's ancestral domain. "Traditionally it is a crime to cut trees, but during drought times trees are cut for animals" (Clan Leader, Buti, 14.11.2013). Alterations to vegetation must be carried out with consent, and clan members or outsiders who remove or damage flora without permission are punished. 


\section{Results}

\subsection{Transitions of natural resource management: changes and adaptation strategies}

"During the past 10 years, all land and rains have changed. When we tried to create wells or prevent further erosion, the water power was too great and we failed. One month after rains, we feed our animals from tree cuttings, no grass is found on the ground. So we cut the trees and shortly all trees are gone and we must go to the highlands for food" (Male Elder, Hiddalu, 31.10.2013).

Both female and male residents stated that a lack of water and recurrent droughts are the most detrimental threats. The repeated and lengthy nature of these droughts e the last serious one, Arkakis ("Terrifying"), 2002/3 to $2007 / 8$ (ANRS, 2008) e strengthen their belief that droughts are no longer abnormal occurrences. Rainy seasons have changed too; Karma (June to September) and Sugum (March to April) are shorter and Dadda (December) has disappeared. The increase in sporadic and variable rainfall patterns has been instrumental in the diminished capacity of soil to absorb water (Meze-Hausken, 2004). The amount of time that water remains in seasonal rivers following rains has decreased, from up to three months to only three days. "When rains come, they pass too quickly. In the morning maybe you can find water, once rain stops you can only find water in wells and pits. Water doesn't remain, only stays for one day" (Male Elder, Hiddalu, 29.10.2013). This has led to a stark reduction in the capacity of traditional water points, or buyyi, to produce water and increased the frequency with which residents lacking permanent, nearby water sources have to travel. The effects on males and females differ; males must spend more time finding suitablewatering points for animals, and females must spend more time collecting water for human consumption. All females interviewed reported that the time and/or distance required to collect water has increased over the past 10 years and continues to increase annually. As local points dry up, more time is spent collecting water both due to an increase in distance between the points and, when drawing from wells or tanks, an increase in people using one water source. Hiddalu females without a permanent water source make return trips of up to eleven hours every two to three days to collect water; "we wake up at 3 am and come back at 2 pm, sometimes every second day and sometimes every third" (Hiddalu Females, 27.10.2013). While this trip was previously only done between rainy seasons, the disappearance of the December rains and shortening of the other rainy seasons mean the trip is made almost all year long, the exception being during rains and the days immediately following.

The second largest threat reported by residents is erosion. "The land is thirsty and crying like the kid that misses its mother. It needs water but we don't know what to do." (Male Elder, Buti, 14.03.14). Residents reflected on the recent inability of rangelands to retain flash flood water, water previously utilised for regenerative purposes. The amount of water funnelled directly into seasonal and perennial rivers and not absorbed by pastures is increasing annually, and flash floods also exacerbate erosion caused by road construction. Increased stream bank erosion removes riverbank flora that formerly provided fodder and fruits for human consumption. The most common example of residents working to restore or prevent further destruction is when communal buildings in settlement centres are threatened by extreme weather events, such as flash flooding. Other limited and insufficient restoration attempts include hillside terracing, filling in gullies, and local gabion construction in riverbeds and erosion gullies. Erosion is difficult to curtail partially due to the size of the rangelands and the low population density. Several governmental and non-governmental projects deal with erosion control but a preference for techniques that function in the Ethiopian Highlands, including hillside terracing and gabion construction, cannot adequately address problems forged in the lowlands. Gabions are either washed away or water erodes surrounding land; each year, gullies extend further, wider, and deeper. For example, an irrigation weir gabion constructed in 2012 in Ewa was damaged during the following rainy season and locals have been unable to repair it due to a lack of appropriate equipment and knowledge.

Throughout the focus region residents reflected on a stark decrease in availability and quality of pastures over the past three decades. The lack of rains and increased erosion have worsened rangeland conditions, a change perceived by the Afar to be the prime catalyst for decreasing herd sizes (Meze-Hausken, 2004; Tsegaye et al., 2010a). "Lots of people and animals were here [...] They started to disappear 20 years ago. Trees and grasses are gone due to a lack of water and no one has done anything to bring them back" (Male Elder, 1st Badoli, 11.11.2013). Residents across all four kebeles reported that the initial signs of decreasing grass regeneration were seen in 1996 but have increased in severity since 2007. Rangelands now provide less essential grazing 
pasture, such as durfu (Chrysopogon plumolosus) and malif (Andropogon canaliculatus), and weakened livestock die due to the increased distances between overcrowded and overgrazed stations. A local preference for cattle, combined with a lack of suitable fodder, contributed to livelihood vulnerability after prolonged droughts caused livestock to die and inhabitants unable to restock animals. This brought about a preference for browsers, which are more apt at digesting dry-matter pasturage and can survive longer without water. Another rangeland management challenge throughout Afar is the widespread invasion of alien flora such as Prosopis (Rettberg and Müller-Mahn, 2012) and Partinium, plants that grow in abundance in poor soil. Partinium, locally known as "democracy", threatens farming and when consumed by livestock turns milk bitter. Residents stated that a hectare plot can become overrun in a month if not strictly controlled. The expansion of Garunta (Acacia nubica), while a native plant, is also perceived as detrimental to crops and livelihoods. "Garunta is not interesting for humans or livestock. It provides cover for hyenas and other animals that attack livestock, and grass can't grow in the same area" (Male Elder, 1st Badoli, 11.11.2013). Residents of 1st Badoli removed A. nubica plants from their settlement in 2011, but the plant's proliferation into rangelands was too severe and widely dispersed to effectively manage.

In contrast to other areas within Afar and the Somali Region where charcoal production is prominent and exacerbates rangeland degradation (Devereux, 2006; Kassahun et al., 2008; Oduori et al., 2011), in the study region deforestation is primarily performed for local use only. Cutting down trees for firewood is more severe near kebele and woreda centres, while the breaking of tree branches to provide fodder for livestock is more prominent in remote areas. Traditional leaders in Ewa have relinquished their control over traditional deforestation prevention practices, placing responsibility upon government officials. "We know it is bad for the land, but we must feed our animals. [...] Before, people used to take permission from clan leaders; that time is passed. Nowit is the time of the government" (Buti Clan Leader, 14.11.2013). Permission is no longer sought from clan leaders, and leaders no longer punish culprits; the presence and importance of coox dacayri has deteriorated. The reduction in phytomass also leads to changes to traditional housing construction; due to insufficient quantities of thelocal grass gorrobu (Panicum coloratum), structures are now supplemented by woven mats, plastic sheeting, and fabric. A major shift in rangeland use regulation, previously officiated by clan officials, was the removal of desso in 2004 by government officials. When desso is implemented, those guilty of enforcing it are punished by the government through non-traditional channels. This occurred in Hiddalu in 2009, when the clan and youth leaders were found guilty of applying desso and sentenced to four months in prison. Rangelands and pastures once locally managed are increasingly run by government officials, with clan leaders engaged for cultural support.

A decline in the number of functioning and accessible stations and rangelands causes migration problems and promotes hostility. For example, changes to rangelands have sent the Afar into neighbouring Amhara and Tigray highland regions, increasing conflicts. In 2012/13, Ewa pastoralists preferred to go to Amhara, particularly Habru, Kamise, and Kobo Woredas, despite entrance restrictions placed upon highland rangelands by the Amhara; i.e., access taxes. While no complete official records exist detailing the number of deaths, casualties, or acts of livestock theft, between 2006 and 2010 there were 22 reported Afar deaths in the highlands, and livestock raiding was rampant. Kebele government officials, not clan, travel with their constituents into neighbouring ethnic regions prior to anymajor migration to facilitate official introductions and establish access guidelines. While these formal introductions have diminished conflict frequency and intensity, violence has not been eradicated. Rangeland use inside and outside of the Afar Region during the 2013 dry season resulted in conflicts, some of which ended in murder, assault, and theft of weapons and livestock.

\subsection{Changes in property rights and the governmental sedentarisation scheme}

Formally defining property rights for one group often leads to the exclusion of others, thereby creating a new potential conflict source. The move away from communal tenure over rangelands to land privatisation bestows control to a smaller group, even allocating individuals the right to exercise excludability. The privatisation and fragmentation of land restricts access to natural resources and leads to the overgrazing of available rangelands (Hagmann and Alemmaya, 2008), thus increasing competition and conflict potential. 
A strong economic push drives the privatisation commonplace in various African countries (Mwangi, 2007; Mwangi and Dohrn, 2008) as governments benefit from leasing land to foreign countries and the conversion of land to state farming. Land grabs in Afar include those done to facilitate large-scale sugarcane plantations (Müller-Mahn et al., 2010), a change that damages the local ecosystem. This form of privatisation also impacts livelihood practices, as land bordering perennial rivers provides dry season sustenance to locals and those originating from more arid regions. However, this paper focuses on the consequences of land privatisation through sedentarisation and small-scale farming.

The Ethiopian Government's sedentarisation policy, an attempt to improve livelihood security and decrease reliance on government support, was created in 2003 after deeming that rural agricultural efforts were inadequate and unable to provide sufficient food for those in drought-afflicted regions (GFDRE, 2003). But sedentarisation also increases the state's control over nomadic peoples (Lavers, 2012b), enhances the potential to tax rural peoples, and impacts socio-cultural practices (Stratford and Davidson, 2002). This policy has been accompanied by modernisation efforts (Makki, 2012) such as amendments to property rights, and has brought on the types of challenges around land tenure reform already witnessed in numerous African countries (Peters, 2008). An example is South Africa's Namaqualand region, where a formalisation of the commons that was designed to curb land degradation and decrease poverty actually increased impoverishment (Lebert and Rohde, 2007).

The 2008 Afar National Regional State Rural Lands Administration and Use Policy, which introduced codified property rights, facilitates a move away from the traditional understanding of communal natural resource ownership towards one of privatised ownership. It entails the privatising of rangelands through the regulation of grazing rights and resource access down to a household level. Rural regions and rangelands in Afar that do not have codified ownership rights are the common shared property of the Ethiopian Government and the Afar. Article 40(5) of Ethiopia's constitution states: "Ethiopian pastoralists have the right to free land for grazing and cultivation as well as the right not to be displaced from their own lands" (ANRS, 2008, 7). The policy aims to provide a legal tenure over the commons, reiterating that traditional property rights in Afar are not perceived to be tantamount to modern laws as seen in other sub-Saharan countries (Alden Wily, 2011). However, the processes undertaken to privatise land are not well understood by local residents (see also Mwangi, 2007). Unlike under past policies, i.e., during the Derg Regime (Rettberg, 2010), land titles awarded to outside bodies (e.g., for large-scale agricultural investments) should be granted in conjunction with compensation paid to clans with ancestral claim over the land; those with secondary level access receive no remuneration (ANRS, 2008).

Changes to property rights allow for private ownership, permitting land to be leased, bequeathed, and inherited but not sold (ANRS, 2008). The Government's position is that the prevention of sales will protect the impoverished (GFDRE, 2003). But while this step may preclude the immediate sale of land, it has not stopped the unofficial leasing of lands to highlanders, which could potentially result in more displaced peoples, as seen in other sub- Saharan countries (Peters, 2008). An additional concern that has not been addressed is whether the current allocated plot size will be able to produce adequate crops once divided between heirs. The sustainability of this approach is thus questionable, particularly in regions with limited water access where the potential for future conflicts is high once all appropriate land has been allocated. Current government practice awards plots of between 0.5 and 1.5 to households based on their size; households are traditionally determined around a male, his wife or wives, and their children. Government cleared and irrigated land is given to applicants on a 'first come, first served' basis (Woreda Head, Awra, 20.10.2015), with a focus on agro-pastoralist kebeles whose residents are the only ones awarded land titles. To be constitutionally classified as a resident, one must reside in the area for four years or more. While it is permitted for females to own land, un-married women or widows with children are able to register for land ownership, they are granted smaller plots as they are deemed less capable than men. Gender equality with regards to formal property rights is lacking in Ethiopia (Crewett and Korf, 2008) as in other African dryland regions (Mwangi and Dohrn, 2008).

Land chosen for settlement projects should be 'unoccupied land' (GFDRE, 2003, 41), however this is not the case in the focus areas. In Awra, the chosen settlement zone Hida has functioned as an agropastoralist kebele for more than 12 years, with residents holding both codified and unofficial land titles. In Ewa, the Horongo settlement site has been constructed on a traditional rangeland; in March 2014 rangeland access was still possible for pastoralists because only approximately 1000 households had been settled. However as the program 
continues complete access will be denied once the whole rangeland is converted into farmland, as seen already in some places of the Somali Region (Devereux, 2006). "Today the rich man is the one who owns the farm" (Agropastoralist, Hida, 19.11.2013). Public interest in the settlement scheme stems from more than governmental guidance and there is a difference in how sedentarisation is perceived by each gender. Males see it as necessary response to the failing pastoralist system, while females emphasise the additional services it can provide and are drawn to visible rural development; i.e., education, health services, and specifically access to clean water. Another mitigating factor is a proximity to roads, allowing for faster access to delivered food aid. Residents and government officials alike reflect the growing dependence on food aid during dry seasons and extended periods of drought. While farming is not representative of Afar culture, it is not a new concept. In the focus area land was originally cultivated during the Derg Regime in 1972; however, after the regime fell the area became overgrown. Farming is dependent on a proximity to a perennial water source. Attempts to cultivate land through rainwater harvesting were thwarted due to insufficient water, and Hiddalu residents endeavoured unsuccessfully for two years to produce crops (2006e7). Importantly, land with perennial water sources does not ensure success. Crops can fail when too many farms rely on irrigation water sources or from poor water management.

\section{Discussion: pastoralist to agro-pastoralist}

"Pastoralism is honey because man is able to get the financial support he needs from the sale of livestock. Agriculture is like milk because when you drink milk your stomach is full and it cools you down. Both do not share the same advantages, but when the two are combined the quality of life improves." (Clan Leader, Hida, 10.10.2013).

Empirical data show that intensified needs for livelihood diversification and interests in sedentarisation and agriculture are the result of changes in access to, the conditions and governance of natural resources. Residents turn to introduced livelihood practices, which do not address the increasing problem of rangeland degradation as a whole. Two key transitions, from traditional to formal governance and from pastoralism to agro-pastoralism, have created a liability gap in natural resource management; neither pastoralists nor agro-pastoralists believe themselves to be responsible for and in charge of rangeland management. Traditional leaders increasingly denounce indigenous practices, deeming them insufficient, and assert that management is the government's responsibility. Within Zone Four a prominent resident belief exists that land management is the duty of the sedentary Afar. While agropastoralists do utilise introduced techniques to protect land when farming, these techniques are typically only applied to their immediate surroundings and not into adjacent rangelands where pure pastoralists no longer use traditional practices. Thus the role of local land management is left unattended and rangelands continue to deteriorate. Additionally, privatisation reduces accessible rangelands and the removal of traditional exclusion activities has led to the intensified usage of the remaining communal rangelands. This results in deteriorated pastoralist livelihoods and worsening livestock conditions.

Land privatisation for small-scale farming, although not proportional to large-scale agricultural investments, impacts the present population and most importantly, future ones through restricted access. Advocating agriculture leads to barring pastoralist entry into rangelands designated for small-scale farming. Agropastoralism is perceived to be capable of providing greater livelihood security, and typically granting secured access to land serviced by either perennial rivers or ground water sources. As agro-pastoralist numbers grow, increasing the presence of farmland and decreasing access for pastoralists to fertile areas, so does the potential for a new form of land and natural resource based conflicts. Changes in property rights, transitioning from a culture where land was neither private nor able to be bequeathed, to one where it is possible, occur seemingly without recognition of the consequences. Afar culture doesn't embody property inheritance; traditionally land belongs to the clan as a collective. However, land now obtained through sedentarisation can be legally bequeathed. Just how land sufficient to provide for one household will be divided up between offspring and allocated, be they male or female, has not been determined. What bearing this will have on large households that rely solely on farming has not been factored into the settlement project. Worryingly, there is a lack of local awareness as to what impact these significant changes will have in the future. The superficial prescribed terminology of pastoralist and agropastoralist, introduced by the government, simplifies and generalises peoples utilising diverse livelihood practices, resulting in a weak categorisation that does not allow for the complex nature of livelihood practices to be understood. External stakeholders state pastoralist represents those who only carry out animal husbandry and do not incorporate non-traditional practices into their daily lives; a pure pastoralist still utilises indigenous 
practices. An agropastoralist has begun the modernisation process by adopting sedentary livelihood practices; primarily agriculture. An agropastoralist utilises animal husbandry and farming to diversify income-generating activities.

Numerous factors are neither included nor determined by these two terms: how the change is decided and by whom as well as the ramifications felt by the individuals, their families and communities. An agro-pastoralist may belong to a pure-pastoralist family and be the sole household member who has adopted agriculture. Livestock numbers are not necessarily reduced through the conversion, rather absorbed into the family's herd thus the pressure on rangelands is not diminished. What is not taken into account when using these livelihood classifications is the fact that, within Afar, the term pastoralist symbolises much more than a livelihood practice. Since time immemorial the Afar have perceived pastoralism to be an embodiment of the people and synonymous with their identity, a trait shared by other ethnic pastoralists (Upton, 2014). This correlation between a livelihood practice and an ethnic group demonstrates the cultural importance of the heterogeneous relationships between the Afar, their land and herds. Even some urban Afar residing in Logia still identify as pastoralists. How households begin to farm, either voluntary or involuntary, impacts how they fare. Those who voluntarily take up farming are more likely to succeed while failure is more prevalent with those forced to change livelihood patterns, either through the loss of their herd or by external influences. "Treat them where they are. Don't address the position they're not in. Address them in their own address. These people are pastoralists." (Cultural Expert, Logia, 7.11.2013). Whether agriculture will be a temporary measure that ceases once herds are restocked, as with the Maasai (Upton, 2014), or a permanent move remains to be seen.

\section{Conclusions}

Climate change, an increasing government presence, the transition away from common property regimes and modernisation processes are transforming Afar landscapes, culture, and livelihoods. Recurrent droughts, decreasing rains, erosion processes, rangeland degradation or the loss of rangelands through land acquisition and small-scale farming threaten Afar livelihoods. Several of these threats have not been witnessed during the lifespan of current elders and indigenous management systems previously sufficient are now deemed incapable of curbing physicalalterations or the increasing pressures on rangelands. Changes to Afar culture have been driven by the demotion of pastoralism as the preferred livelihood practice and the devaluation of the traditional governance systems. As traditional management techniques loose popularity and relevance, the control that traditional governance institutions wield weakens. Pastoralism is no longer seen as the paramount livelihood practice, a shift influenced by the mentioned environmental changes, sedentarisation schemes, and institutional alterations.

To deal with the deteriorating state of natural resources, numerous issues need to be addressed so that the most suitable management regimes can be put into practice. Lessons learnt from and the appropriation of methods found in similar arid and semiarid environments would be more suited to Afar, as opposed to those used in the Ethiopian highlands. Management regimes must also consider workforce availability in the sparsely populated vast Afar lowlands and individual goals of the concerned. Programs paying residents to work on natural resource management, while temporarily assisting their economic well-being, increase local reluctance to act without external support or payment. This constrained level of participation is further weakened by the pastoralists' belief that land management is the duty of agro-pastoralists.

The transition from communal land to private ownership has, partially, been done under the guise of improving the welfare of the Afar. Institutional change in Afar has diminished the strength of traditional leaders and empowered the government. Altering the common property regime used by the Afar reduced the power of customary institutions and has been a driving force behind the diversification of livelihoods; private land ownership draws the Afar away from pure pastoralism and towards agriculture. Small-scale farming reduces pastoralist access to natural resources, as do unprecedented changes in property rights. Transitioning from a commonproperty regime towards landprivatisation, without considering conceivable future negative repercussions, has clear potential to increase natural resource conflicts within an already conflict-laden region. Local comprehension of the possible consequences is worryingly low to non-existent. For current settlement programs in Afar to be successfully implemented and utilised by future generations, inheritance concerns need to be realised and addressed. 
Livelihood changes also alter the cultural identity of the Afar. No longer is pastoralism synonymous with Afar livelihoods. If and how pastoralists and agro-pastoralists are capable of adjusting to fit into a changing Afar, both now and in the future, is still to be seen. Further studies would be required to expand on how the introduced livelihood classification, 'agro-pastoralist', impacts Afar culture and identity.

Institutional and policy support of traditional pastoralism practices, which would strengthen and assist the Afar, is insufficient. As the fragmentation of communal lands through privatisation does not necessarily enhance livelihoods (Bassett, 2009), as seen in other regions (Bennett et al., 2010), official institutional rangeland management needs to be appropriately addressed in order to sustainably utilise this sparse semi-arid region and provide secure livelihoods for its residents.

\section{Acknowledgement}

We would like to thank the Deutsche Gesellschaft fuer Internationale Entwicklung (GIZ) for their financial and logistical support. We highly appreciate the valuable comments from two anonymous reviewers that significantly helped us to rethink and rework our paper.

\section{References}

Abule, E., Snyman, H.A., Smit, G.N., 2005. Comparisons of pastoralists' perceptions about rangeland resource utilisation in the middle Awash Valley of Ethiopia. J. Environ. Manag. 75, 21e35.

Agrawal, A., 2001. Common property institutions and sustainable governance of resources. World Dev. $29,1649 \mathrm{e} 1672$.

Agrawal, A., 2014. Studying the commons, governing common-pool resource outcomes: some concluding thoughts. Environ. Sci. Policy 36, 86e91.

Alden Wily, J., 2011. The law is to blame: the vulnerable status of common property rights in SubSaharan Africa. Dev. Change 42, 733 e757.

Alden Wily, L., 2012. Looking back to see forward: the legal niceties of land theft in land rushes. J. Peasant Stud. 39, 751e775.

ANRS (Afar National Regional State), 2008. Afar National Regional State Rural Lands Administration and Land Use Policy. Semara, Ethiopia.

ANRS (Afar National Regional State), 2011a. Afar National Regional State Awra Technical Report: Land Degradation Assessment. Semara, Ethiopia.

ANRS (Afar National Regional State), 2011b. Afar National Regional State Ewa Technical Report: Land Degradation Assessment. Semara, Ethiopia.

Araral, E., 2014. Ostrom, Hardin, and the commons: a critical appreciation and a revisionist view. Environ. Sci. Policy 36, 11e23.

Ayantundea, A.A., de Leeuwb, J., Turner, M.D., Said, M., 2011. Challenges of assessing the sustainability of (agro)-pastoral systems. Afar Natl. Reg. State Livest. Sci. 139, 30e43.

Aynekulu, E., Aerts, R., Moonen, R., Denich, M., Gebrehiwot, K., Vågen, T., Mekuria, W., Boehmer, H.J., 2012. Altitudinal variation and conservation priorities of vegetation along the great rift valley escarpment, northern Ethiopia. Biodivers. Conserv. 21, 2691e2707.

Bassett, T., 2009. Mobile pastoralism on the brink of land privatization in Northern Côte d'Ivoire. Geoforum 40, $756 \mathrm{e} 766$.

Behnke, R., Scoones, I., Kerven, C. (Eds.), 1993. Range Ecology at Disequilibrium: New Models of Natural Variability and Pastoral Adaptation in African Savannas. Overseas Development Institute, London.

Bennett, J., Ainslie, A., Davis, J., 2010. Fenced in: common property struggles in the management of communal rangelands in central Eastern Cape Province, South Africa. Land Use Policy 27, 340e350.

Berhanu, W., Colman, D., Fayissa, B., 2007. Diversification and livelihood sustainability in a semi-arid environment: a case study from southern Ethiopia. J. Dev. Stud. 43, 871e889. 
Berkes, F. (Ed.), 1989. Common Property Resources: Ecology and Community-based Sustainable Development. Belhaven Press, London.

Borras, S.M., Hall, R., Scoones, I., White, B., Wolford, W., 2011. Towards a better understanding of global land grabbing: an editorial introduction. J. Peasant Stud. 38, 209e216.

Cousins, B., 2007. More than socially embedded: the distinctive nature of 'communal tenure' regimes in South Africa and its implications for land policy. J. Agrar. Change 7, 281e315.

Cotula, L., 2012. The international political economy of the global land rush: a critical appraisal of trends, scale, geography and drivers. J. Peasant Stud. 39, 649e680.

Cox, M., Arnold, G., Tom_as, S.V., 2010. A review of design principles for communitybased natural resource management. Ecol. Soc. 15 (4), 38.

Crewett,W., Korf, B., 2008. Ethiopia: reforming land tenure. Rev. Afr. Polit. Econ. 35, 203e220.

Davies, J., Bennett, R., 2007. Livelihood adaptation to risk: constraints and opportunities for pastoral development in Ethiopia's Afar region. J. Dev. Stud. 43, 490e511.

Devereux, S., 2006. Vulnerable Livelihoods in Somali Region, Ethiopia. Institute of Development Studies Research Report 57, Brighton.

Easdale, M.H., Domptail, S.E., 2014. Fate can be changed! Arid rangelands in a globalizing world: a complementary co-evolutionary perspective on the current 'desert syndrome'. J. Arid Environ. $100 \mathrm{e} 101,52 \mathrm{e} 62$.

Galaty, J., 2013. Land grabbing in the eastern African Rangelands. In: Catley, A., Lind, J., Scoones, I. (Eds.), Pastoralism and Development in Africa: Dynamic Change at the Margins. Routledge, New York, pp. 143e153.

Government of the Federal Democratic Republic of Ethiopia (GFDRE), 2003. Rural Development Policy and Strategies. Addis Ababa.

Hagmann, T., Alemmaya, M., 2008. Pastoral conflicts and state-building in the Ethiopian lowland. Afr. Spectr. 43, $19 \mathrm{e} 37$.

Hanna, S., Folke, C., M€aler, K.-G. (Eds.), 1996. Rights to Nature: Ecological, Economic, Cultural, and Political Principles of Institutions for the Environment. Island Press, Washington D.C.

Hardin, G., 1968. The tragedy of the commons. Science 162, 1243e1248.

Headey, D., Taffesse, A.S., You, L., 2014. Diversification and development in pastoralist Ethiopia. World Dev. 56, 200e213.

Hundie, B., Padmanabhan, M., 2008. The Transformation of the Afar Commons in Ethiopia: State Coercion, Diversification, and Property Rights Change among Pastoralists Collective Action and Property Rights. IFPRI No. 87,Washington D.C.

Kassahun, K., Snyman, H.A., Smit, G.N., 2008. Impact of rangeland degradation on the pastoral production systems, livelihoods and perceptions of the Somali pastoralists in Eastern Ethiopia. J. Arid Environ. 72, 1265e1281.

Lavers, T., 2012a. 'Land grab' as development strategy? The political economy of agricultural investment in Ethiopia. J. Peasant Stud. 39, 105e132.

Lavers, T., 2012b. Patterns of agrarian transformation in Ethiopia: state-mediated commercialisation and the 'land grab'. J. Peasant Stud. 39, 795e822.

Lebert, T., Rohde, R., 2007. Land reform and the new elite: exclusion of the poor from communal land in Namaqualand, South Africa. J. Arid Environ. 70, 818e833.

Makki, F., 2012. Power and property: commercialization, enclosures, and the transformation of agrarian relations in Ethiopia. J. Peasant Stud. 39, 81e104. 
Meier, P., Bond, D., Bond, J., 2007. Environmental influences on pastoral conflict in the Horn of Africa. Polit. Geogr. 26, 716e735.

Meze-Hausken, E., 2004. Contrasting climate variability and meteorological drought with perceived drought and climate change in northern Ethiopia. Clim. Res. 27, $19 \mathrm{e} 31$.

Ministry of Finance and Economic Development Economic Policy and Planning Department (MFEDEPPD), 2003. Rural Development Policy and Strategies. Addis Ababa.

Müller-Mahn, D., Rettberg, S., Getachew, G., 2010. Pathways and dead ends of pastoral development among the Afar and Karrayu in Ethiopia. Eur. J. Dev. Res. 22, 660e677.

Mwangi, E., 2007. Subdividing the commons: distributional conflict in the transition from collective to individual property rights in Kenya's Maasailand. World Dev. 35, 815e834.

Mwangi, E., Dohrn, S., 2008. Securing access to drylands resources for multiple users in Africa: a review of recent research. Land Use Policy 25, 240e248.

Nassef, M., Anderson, S., Hesse, C., 2009. Pastoralism and Climate Change: Enabling Adaptive Capacity. Humanitarian Policy Group. Overseas Development Institute, London.

Odote, C., 2013. The dawn of Uhuru? Implications of constitutional recognition of communal land rights in pastoral areas of Kenya. Nomadic Peoples 17, 87e105.

Oduori, S.M., Rembold, F., Abdulle, O.H., Vargas, R., 2011. Assessment of charcoal driven deforestation rates in a fragile rangeland environment in North Eastern Somalia using very high resolution imagery. J. Arid Environ. 75, 1173e1181.

Okello, M.M., Ole Seno, S.K., Nthiga, R.W., 2009. Reconciling people's livelihoods and environmental conservation in the rural landscapes in Kenya: opportunities and challenges in the Amboseli landscapes. Nat. Resour. Forum 33, 123e133.

Onono, J.O., Wieland, B., Rushton, J., 2013. Constraints to cattle production in a semi-arid pastoral system in Kenya. Trop. Anim. Health Prod. 45, 1415e1422.

Ostrom, E., 1990. Governing the Commons: the Evolution of Institutions for Collective Action. Cambridge University Press, Cambridge.

Ostrom, E., 2009. A general framework for analyzing sustainability of socialeecological systems. Science $325,419 \mathrm{e} 422$.

Ostrom, E., Dietz, T., Dol_sak, N., Stern, P.C., Stonich, S., Weber, E. (Eds.), 2002. The Drama of the Commons. National Academy Press, Washington D.C.

Peters, P., 2008. Challenges in land tenure and land reform in Africa: anthropological contributions. World Dev. 37, 1317e1325.

Peters, P., 2013. Land appropriation, surplus people and a battle over visions of agrarian futures in Africa. J. Peasant Stud. 40, 537e562.

Quinn, C., Huby, M., Kiwasila, H., Lovett, J., 2007. Design principles and common pool resource management: an institutional approach to evaluating community management in semi-arid Tanzania. J. Environ. Manag. 84, 100e113.

Raleigh, C., Kniveton, D., 2012. Come rain or shine: an analysis of conflict and climate variability in East Africa. J. Peace Res. 49, 51e64.

Rettberg, S., 2010. Contested narratives of pastoral vulnerability and risk in Ethiopia's Afar region. Pastor. Res. Policy Pract. 1, 248e273.

Rettberg, S., Müller-Mahn, D., 2012. Human-environment interactions: the invasion of Prosopis Juliflora in the drylands of Northeast Ethiopia. In: Mol, L., Sternberg, T. (Eds.), Changing Deserts. Cambridge Whitehorse Press, Cambridge, pp. 297e316. 
Rich_e, B., Hachileka, E., Awuor, C.E., Hammill, A., 2009. Climate Related Vulnerability and Adaptive Capacity in Ethiopia's Borana and Somali Communities. International Institute for Sustainable Development, Winnipeg. Final Assessment Report.

Sietz, D., Lüdeke, M.K., Walther, C., 2011. Categorisation of typical vulnerability patterns in global drylands. Glob. Environ. Change 21, 431e440.

Smalley, R., Corbera, E., 2012. Large-scale land deals from the inside out: findings from Kenya's Tana Delta. J. Peasant Stud. 39, 1039e1075.

Sonneveld, B.G., Pande, S., Georgis, K., Keyzer, M.A., Seid Ali, A., Takele, A., 2010. Land degradation and overgrazing in the Afar region, Ethiopia: a spatial analysis. In: Zdruli, P., Pagliai, M., Kapur, S., Faz Cano, A. (Eds.), Land Degradation and Desertification: Assessment, Mitigation and Remediation. Springer, Dordrecht, pp. 97e110.

Stratford, E., Davidson, J., 2002. Capital assets and intercultural borderlands: sociocultural challenges for natural resource management. J. Environ. Manag. 66, 429e440.

Sulieman, H.M., Elagib, N.A., 2012. Implications of climate, land-use and land-cover changes for pastoralism in eastern Sudan. J. Arid Environ. 85, 132e141.

Tsegaye, D., Moe, S.R., Vedeld, P., Aynekulu, E., 2010a. Land-use/cover dynamics in Northern Afar rangelands, Ethiopia. Agric. Ecosyst. Environ. 139, 174e180.

Tsegaye, D., Haile, M., Moe, S.R., 2010b. The effect of land use on the recruitment and population structure of the important food and fodder plant, Dobera glabra (Forssk.) Poir., in northern Afar, Ethiopia. J. Arid Environ. 74, 1074e1082.

Tsegaye, D., Vedeld, P., Moe, S.R., 2013. Pastoralists and livelihoods: a case study from northern Afar, Ethiopia. J. Arid Environ. 91, 138e146.

Upton, C., 2014. The new politics of pastoralism: identity, justice and global activism. Geoforum 54, $207 \mathrm{e} 216$.

Woodhouse, P., 2012. New investment, old challenges. Land deals and the water constraint in African agriculture. J. Peasant Stud. 39, 777e794.

Whitfield, S., Reed, M., 2012. Participatory environmental assessment in drylands: introducing a new approach. J. Arid Environ. 77, 1e10. 